\title{
PENGEMBANGAN PARIWISATA HALAL DESA SETANGGOR
}

\author{
Feriyadin', Akhmad Saufi ${ }^{2}$, Baiq Handayani Rinuastuti ${ }^{3}$ \\ 1Fakultas Ekonomi dan Bisnis, Universitas Mataram. E-mail: feriyadin@gmail.com \\ ${ }^{2}$ Fakultas Ekonomi dan Bisnis, Universitas Mataram. E-mail:akh.saufi@gmail.com \\ ${ }^{3}$ Fakultas Ekonomi dan Bisnis, Universitas Mataram. E-mail: hrinuastuti@yahoo.com
}

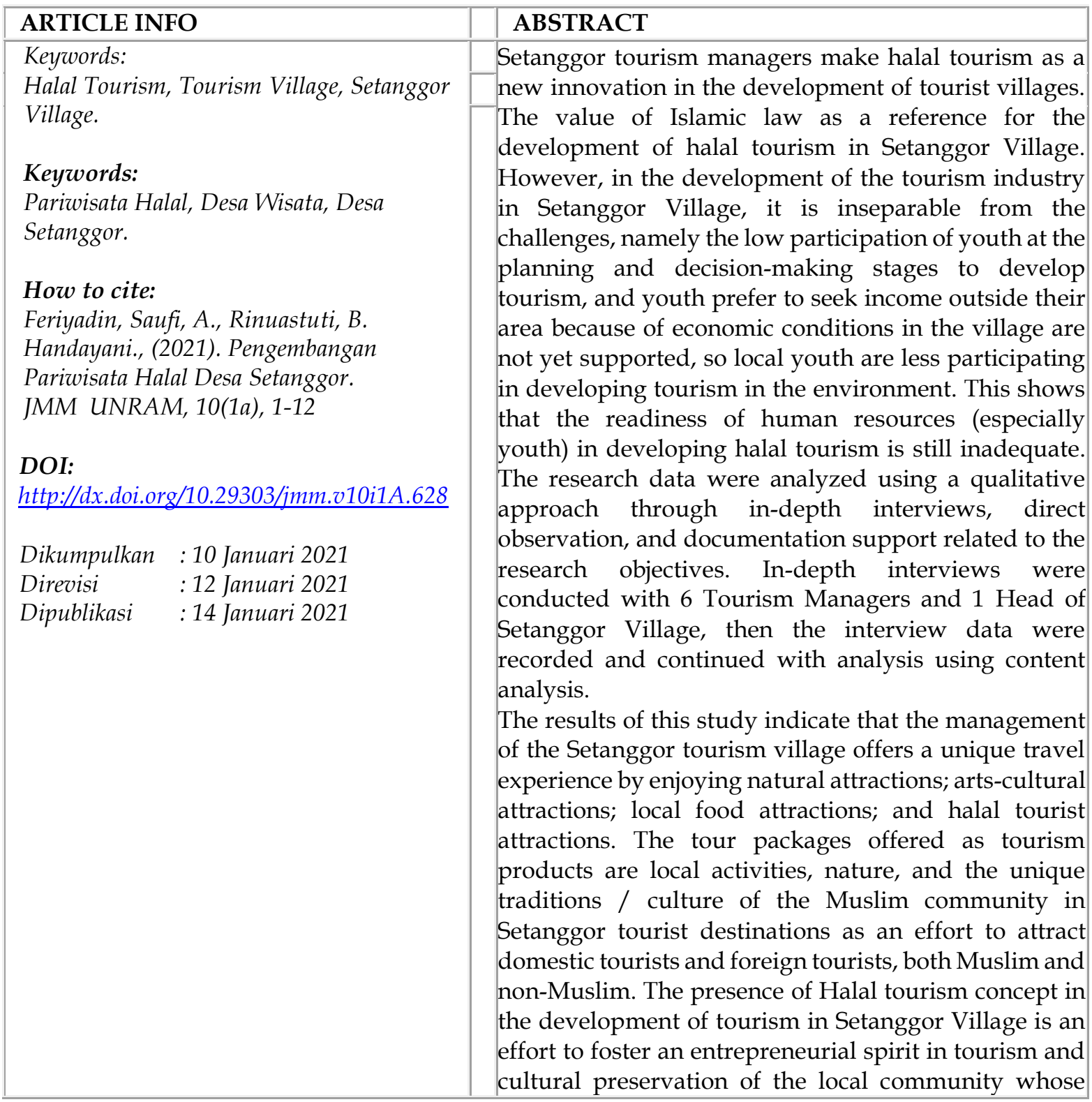




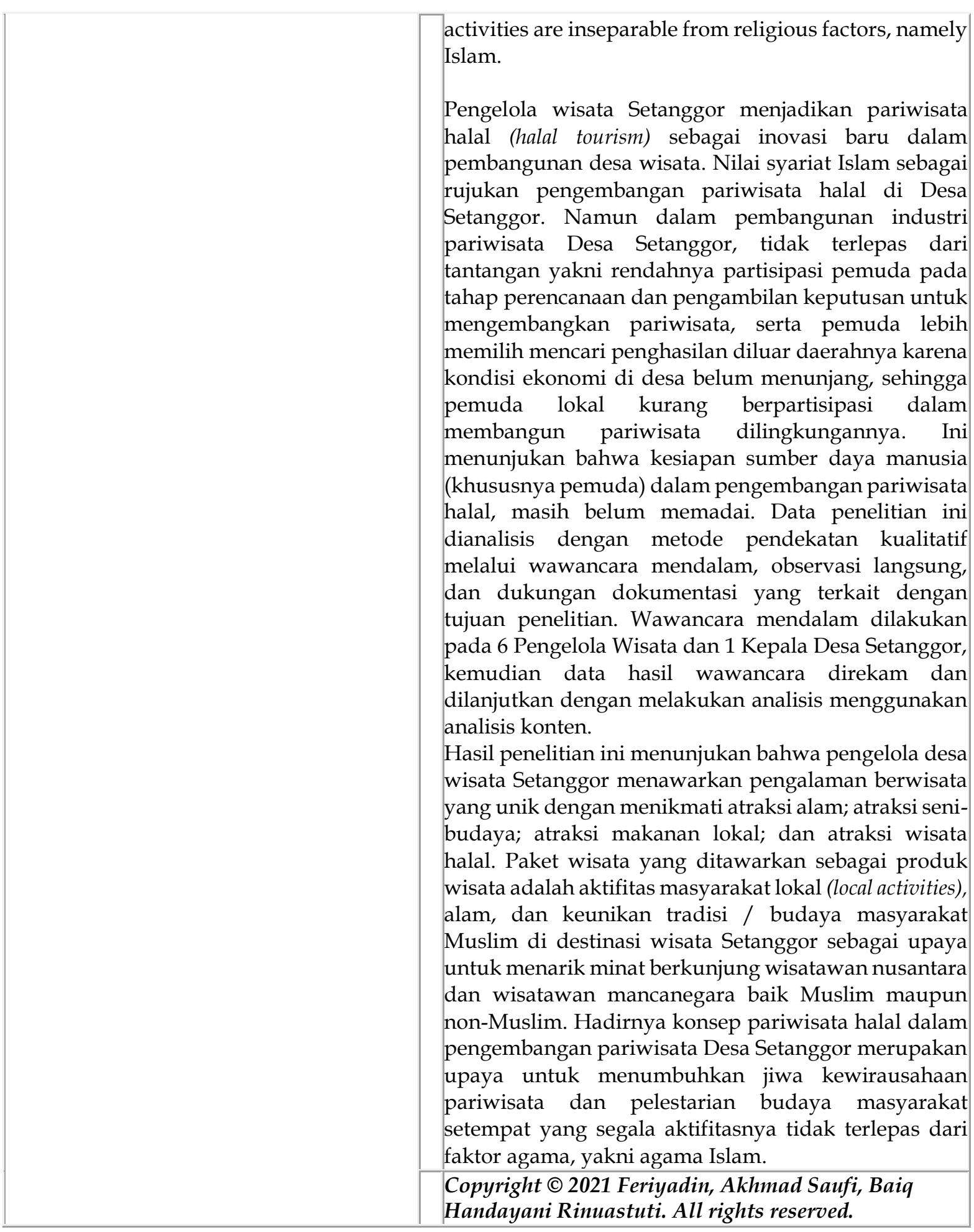




\section{PENDAHULUAN}

Sejak lima tahun terakhir, Lombok yang berada di wilayah Nusa Tenggara Barat diantara destinasi-destinasi yang ada di Indonesia, telah ikut berpartisipasi dalam World Halal Travel Summit yang diselenggarakan di Abu Dhabi selama dua tahun berturut-turut (2015-2016). Alhasil, Lombok meraih predikat: destinasi wisata halal terbaik dunia; pariwisata halal honeymoon terbaik dunia; serta laman wisata halal terbaik (CrescentRating, 2016). Sedangkan dalam negeri, Lombok juga terpilih sebagai destinasi wisata halal terbaik di Indonesia mengungguli daerah lainnya (Kemenparekraf, 2019).

Mengingat Lombok telah mampu meraih sertifikasi "Halal" tingkat nasional dan internasional beberapa tahun yang lalu. Pemerintah daerah sedang gencar-gencarnya mengembangkan pariwisata halal dengan diterbitkannya Peraturan Daerah (Perda) Nomor 2 Tahun 2016 tentang Pariwisata Halal, guna mendukung pengembangkan pariwisata halal di Lombok. Disamping itu, upaya yang dirumuskan oleh pemerintah daerah untuk meningkatkan daya saing pariwisata Lombok ialah bekerjasama dengan MUI dan LPPOM serta Dinas Kebudayaan dan Pariwisata untuk melakukan sertifikasi halal pada restoran hotel, restoran non hotel, rumah makan dan UMKM (Satriana \& Faridah, 2018), serta mutu pelayanan pariwisata yang mengutamakan budaya dan nilai-nilai agama (Jaelani, 2017), yang ditindaklanjuti dengan pembentukan 99 desa wisata di Lombok-Sumbawa (ntbprov.go.id, 2019).

Melalui pembangunan wisata pedesaan, dapat memberikan kesempatan bagi desa untuk menganekaragamkan kegiatan di desa sehingga mampu membuka peluang lapangan pekerjaan (usaha) yang luas bagi penduduk desa (Priasukmana \& Mulyadin, 2001), meningkatkan penghasilan masyarakat; menumbuhkan rasa kepemilikan dan kontrol masyarakat lokal; serta menambah pendapatan pemerintah melalui retribusi wisata (Hermawan, 2016) guna mendukung prioritas pengembangan destinasi wisata.

Sebuah desa yang termasuk dalam pilot project (desa wisata) pemerintah daerah ialah Desa Setanggor, yang berada di wilayah Kabupten Lombok Tengah. Desa ini memiliki posisi yang strategis, letaknya yang dekat dengan Bandara Internaional Lombok (BIL) dengan perkisaran 5 kilometer untuk menyambut wisatawan yang berkunjung ke Lombok, kemudian aksesibilitas menuju Setanggor masih tergolong bagus dan tidak macet, dan keberadaan desa wisata Setanggor juga sebagai penopang adanya pembangunan Kawasan Ekonomi Khusus Mandalika. Maka dari itu, desa wisata Setanggor bisa menjadi opsi (pilihan) tujuan wisata yang sangat potensial dalam menunjang kawasan wisata KEK Mandalika.

Ditambah lagi, Desa Setanggor juga memiliki kekayaan seni budaya seperti: gamelan; seni tari; drama tradisional; kebiasaan dan ritual religius sebagai implikasi dari kehidupan masyarakat suku Sasak (Sukmayeti \& Utami, 2018; Utami, 2020), suguhan makanan minuman tradisional; kekayaan alam; kerajinan tenun berbahan alam; kehidupan sehari-hari; instrumen gong berusia ratusan tahun; tradisi memaos atau membaca naskah lontar; dan atraksi wisata yang dipadukan dengan nilai-nilai Islam seperti wisata ngaji di berugak / balai-balai tengah hamparan sawah memberikan pengalaman baru bagi setiap wisatawan yang datang ke Desa Setanggor, khususnya wisatawan Muslim (BappedaNTB, 2018). Seluruh potensi seperti: keindahan alam; kesenian dan budaya lokal dapat dikemas menjadi produk wisata alternatif yang sangat potensial dalam menarik minat berkunjung wisatawan nusantara dan wisatawan mancanegara baik Muslim maupun non-Muslim.

Namun dalam proses pembangunan industri pariwisata Desa Setanggor, terdapat hambatan dan tantangan. Masyarakat memiliki persepsi buruk tentang dunia pariwisata yang dinilai dapat mempengaruhi efek sosial dan budaya lokal masyarakat. Pariwisata sering kali dikenal dengan citra (image) buruknya oleh masyarakat desa, melihatnya hanya 


\section{NATIONALLY ACCREDITED JOURNAL - DECREE NO. 21/E/KPT/2018}

dari sudut pandang dampak negatif pariwisata, tidak menggunakan prespektif yang holistik. Sebagaimana ungkapan informan "....sementara kita masyarakat ini masih menganggap pariwisata itu hal yang buruk, selalu fikir yang jelek, ....budaya adat istiadat kita akan terkontaminasi, seperti itulah pemikiran masyarakat" (IL04, KD). Sehingga harapan untuk menghadirkan industri pariwisata di desa sebagai sebuah inovasi baru sangat kecil. Hal ini akan berdampak pada ketidak mampuan masyarakat melihat kekuatan dan potensi-potensi wisata yang dimiliki oleh masyarakat Desa Setanggor.

Salah satu cara yang dapat mengintegrasikan seluruh potensi yang ada, yakni menjadikan Desa Setanggor sebagai desa wisata halal, yang setiap pengembangannya tidak merusak nilai-nilai yang dipercayai oleh masyarakat dan kualitas lingkungan tidak mengalami penurunan atau rusak, serta dapat memaksimalkan keuntungan ekonomi untuk masyarakat lokal (Utami, 2020). Karena pariwisata halal membawa dampak positif bagi pengembangan nilai-nilai agama Islam, juga kepatuhan umat Muslim terhadap agamanya (Akyol \& Kilinc, 2014). Hasil serupa juga dikemukakan Pratama (2020) bahwa pariwisata halal menjadi potensi terkuat karena mencerminkan kearifan lokal dan budaya masyarakat Lombok yang mengandung nilai utama yaitu keimanan kepada Allah. Upaya ini dilakukan agar pembangunan desa dalam sektor pariwisata dapat diterima baik oleh masyarakat lokal. Maka dari itu, peneliti tertarik untuk memahami lebih jauh bagaimana konsep pariwisata halal menjadi sebuah inovasi baru dalam mengembangkan aktifitas pariwisata di Desa Setanggor.

\section{KAJIAN PUSTAKA}

\subsection{Pariwisata Halal}

Menyimak tren pariwisata dunia saat ini, jenis pariwisata yang sedang populer adalah pariwisata halal (halal tourism). Hadirnya pariwisata halal, sebagai sebuah segmen pasar baru dalam industri pariwisata, adalah sebuah ikhtiar dalam memenuhi kebutuhan wisatawan Muslim yang memiliki motivasi khusus dengan menyediakan produk dan layanan yang tidak bertentangan dengan syariah Islam (Battour et al, 2011; Battour et al, 2012; Nassar et al, 2015; Sriprasert et al, 2014). Menurut Battour \& Ismail (2016) pariwisata halal adalah setiap objek atau tindakan pariwisata yang diizinkan menurut ajaran Islam yang di jadikan pedoman oleh wisatawan Muslim dalam berwisata. Sehingga segmen pariwisata ini melayani kebutuhan wisatawan dengan cara menyediakan fasilitas, infrastruktur, produk dan layanan serta kegiatan pariwisata yang sesuai dengan pedoman Islam.

Segmen pasar pariwisata halal berkembang pesat tidak hanya di negara-negara Muslim tetapi secara global. Banyak negara termasuk negara-negara Muslim dan negaranegara non-Muslim bersaing untuk menarik wisatawan Muslim dengan memenuhi semua kebutuhan Muslim dalam industri pariwisata (Battour \& Ismail, 2016; Samori, Salleh \& Khalid, 2016). Munculnya produk pariwisata halal di negera-negara yang jumlah penduduk Muslimnya sedikit seperti Singapura, Thailand, Inggris, Hongkong, Jepang, Korea Selatan, Amerika Serikat, Taiwan, Spanyol, dan Jerman lebih banyak disebabkan oleh meningkatnya permintaan pasar pariwisata (demand-driven) dari kalangan wisatawan Muslim (Jafari \& Scoot, 2014).

Sebaliknya kemunculan produk pariwisata halal di negara-negara yang jumlah penduduk Muslimnya banyak seperti Mesir, Bahrain, Arab Saudi, Qatar, Kuwait, Turki, dan negara-negara Muslim yang ada di benua Asia seperti Indonesia dan Malaysia dipengaruhi oleh adanya kekayaan budaya masyarakat lokal yang sesuai dengan ajaran Islam (ZamaniFarahani \& Musa, 2012), kemudian banyaknya situs-situs keagamaan dan budaya yang berkaitan dengan Islam serta adanya ketersediaan makanan halal (Nisthar \& Nufile, 2016; Bastaman, 2018). Maka dari itu, pariwisata halal ini diatur untuk memudahkan para 


\section{NATIONALLY ACCREDITED JOURNAL - DECREE NO. 21/E/KPT/2018}

wisatawan Muslim dalam berkegiatan wisata baik di negera Muslim maupun negara yang secara populasi penduduk Muslimnya sedikit (Battour \& Ismail, 2016; Jafari \& Scott, 2014).

Dari pandangan diatas dapat diartikan bahwa pariwisata halal adalah kegiatan wisata yang sejalan dengan nilai dan prinsip ajaran Islam, yang dapat di libatkan dalam industri pariwisata berupa produk dan layanan untuk memenuhi kebutuhan dasar wisatawan Muslim dan non-Muslin berupa fasilitas (ibadah), makanan dijamin halal, tempat tinggal yang nyaman dan paket perjalanan yang halal. Sebagai pemasar dan penyedia jasa harus bisa memahami karakteristik dari Prilaku wisatawan Muslim (Muslim Tourist Behaviour) dan menyediakan permintaan wisatawan Muslim, dengan memperhatikan seperangkat layanan tambahan yang ditujukan dan diberikan untuk memenuhi pengalaman, kebutuhan, dan keinginan wisatawan, yang disediakan oleh dunia usaha, masyarakat, dan pemerintah (Kementerian Pariwisata, 2019). Maka dari itu, penyediaan produk pariwisata tidak bisa dipisahkan dengan permintaan wisatawan untuk menciptakan pengalaman yang memuaskan bagi wisatawan.

\subsection{Desa Wisata}

Pengembangan desa wisata merupakan salah satu cara terbaik dalam merevitalisasi kearifan lokal guna mengahadapi gempuran budaya internasional yang makin menggerus kearifan lokal yang ada di masyarakat (Jannati, et al, 2020). Kaitannya dengan konsep pengembangan desa wisata, Pearce (1995) mengartikan pengembangan desa wisata sebagai suatu proses yang menekankan cara untuk mengembangkan atau memajukan desa wisata. Atmoko (2014) berharap munculnya desa wisata bisa menjadi model pembangunan wisata berkelanjutan. Yang selaras dengan konsep pembangunan pariwisata berkelanjutan dari World Tourism Organization (WTO) yakni kelangsungan ekologis, kelangsungan sosial budaya, dan kelangsungan ekonomi, baik untuk generasi sekarang maupun generasi akan datang (Suwena, 2010). Maka dari itu, Pembangunan daerah harus berfokus pada potensi daerah berbasis pada local resources yang dimiliki oleh daerah, sehingga melahirkan ekonomi daerah yang tangguh, kompetitif, dan berkelanjutan (Kader, 2019). Artinya kegiatan masyarakat bisa dijadikan sebagai mata pencaharian untuk menambah pemasukan (income) bagi masyarakat dan melestarikan seni budaya yang telah dimiliki oleh Desa (Setanggor).

Menurut Andriani et al (2015) pada dasarnya, tipologi desa wisata di dasarkan atas karakteristik sumberdaya dan keunikan yang dimilikinya dapat dikelompokkan dalam empat kategori yaitu: desa wisata berbasis keunikan sumber daya budaya lokal (adat-tradisi kehidupan masyarakat, artefak budaya, dsb); desa wisata berbasis keunikan sumber daya alam (pegunungan, argo / perkebunan dan pertanian, pesisir-pantai, dsb); desa wisata berbasis perpaduan keunikan sumber daya budaya dan alam (adat tradisi dan pola kehidupan masyarakat, keindahan bentang alam / landscape); dan desa wisata berbasis keunikan aktifitas ekonomi kreatif (industri kerajinan, dsb). Dalam hal ini, maka munculah Desa Setanggor dengan menawarkan keunikan sumber daya tradisi / budaya lokal masyarakat Muslim dan alam sebagai desa wisata. Hal ini didasari oleh kearifan lokal dan keteguhan pada prinsip-prinsip Islam dalam kehidupan sehari-hari yang sangat sinkron dengan konsep pariwisata halal, sehingga pengelola desa wisata dapat melihatnya dari segi penawaran, yang menjadi ciri khas (branding) tersendiri dalam mengembangkan pariwisata di desa.

Menurut para pengelola wisata, pariwisata halal merupakan sebuah inovasi baru dalam menarik minat berkunjung wisatawan Muslim yang dijadikan sebagai segmen pasar baru (new market). Upaya ini dilakukan untuk menarik atensi dan minat berkunjung wisatawan mancanegara, lebih-lebih wisatawan Muslim. Tingginya perkembangan populasi Muslim dunia hingga 2.8 miliar atau 30\% dari populasi dunia pada tahun 2050 (Pew Research, 2015), berdampak pada peningkatan permintaan pasar dan munculnya kebutuhan 


\section{NATIONALLY ACCREDITED JOURNAL - DECREE NO.21/E/KPT/2018}

khusus dari wisatawan Muslim menjadi potensi pasar baru yang nantinya dapat menyumbangkan jumlah wisatawan ke Lombok khususnya ke Desa Setanggor secara signifikan. Melihat peluang-peluang yang telah dipaparkan diatas, pelaku wisata Desa Setanggor berupaya menawarkan pengalaman berwisata yang unik dengan menerapkan konsep pariwisata halal sesuai kearifan lokal. Karena hadirnya aktifitas pariwisata Desa Setanggor disebabkan oleh adanya konsep halal yang diterima oleh masyarakat lokal. Oleh karena itu, branding Setanggor dibuat sesuai dengan karakteristik lokal Muslim untuk menarik minat berkunjung wisatawan.

\section{METODOLOGI PENELITIAN}

Penelitian ini mengadopsi metode kualitatif (qualitative research). Lokasi penelitian dilakukan di Desa Setanggor dengan melakukan teknik sampling purposive terhadap 6 Pengelola Wisata dan 1 Kepala Desa Setanggor. Pengumpulan data dilakukan dengan wawancara mendalam, observasi langsung, dan dukungan dokumentasi yang terkait dengan tujuan penelitian, peneliti menggunakan waktu selama dua bulan terhitung dari Agustus hingga September. Metode wawancara mendalam dilakukan kepada seluruh informan penelitian dengan rentang waktu sekitar 1 - 2 jam lamanya. Informan dalam penelitian akan ditampilkan dalam bentuk singkatan sebagai upaya untuk menjaga kerahasiaan identitas informan, misalnya huruf I ialah Informan, L/P adalah Lakilaki/Perempauan mengacu pada jenis kelamin informan, angka 01 merujuk pada nomor informan, dan KD adalah Kepala Desa dan KDus adalah Kepala Dusun mengarah pada profesi/posisi informan di masyarakat.

Peneliti menggunakan wawancara tidak terstruktur, dimana peneliti tidak menggunakan pedoman wawancara yang sudah tersusun secara sistematis dan lengkap untuk pengumpulan datanya, melainkan hanya menggunakan pedoman atau garis-garis besar permasalahan yang ditanyakan. Semua data hasil wawancara direkam dan dilanjutkan dengan melakukan analisis menggunakan analisis konten dengan cara reduksi data, penyajian data, verifikasi dan penarikan kesimpulan (Miles \& Huberman, 2009). Untuk memastikan informasi yang dibutuhkan telah sesuai dan lengkap, peneliti melakukan konfirmasi kembali (Member check) melalui media lain seperti telepon atau whatsapp pada informan mengingat keadaan pandemi yang tidak memungkinkan bertemu langsung dengan informan untuk memberikan tambahan, konfirmasi dan klarifkasi jika dirasa perlu. Peneliti juga memperkuat temuan yang didapat dengan beberapa hasil penelitian terdahulu serta konsultasi dengan dosen pembimbing. Hal ini membantu verifikasi dan validasi data. 


\section{HASIL DAN PEMBAHASAN}

\subsection{Menggunakan Pendekatan Partisipatif}

Sebelum meminta dukungan dari pemerintah dan stakeholder lainnya, sikap pertama yang dimunculkan oleh masyarakat Desa Setanggor ialah berbuat secara sukarela (swadaya) sebagai wujud keseriusan dalam memulai aktifitas pariwisata di desa. Perilaku seperti ini sejalan dengan salah satu prinsip pengembangan pariwisata berdasarkan Undang-undang No. 10 Tahun 2009 tentang Kepariwisataan pasal 2 yakni Partisipatif. Karena modal dasar dalam mensukseskan program pembangunan desa, khususnya pada sektor pariwisata ialah kesungguhan dari masyarakat lokal untuk berbuat secara swadaya, dengan memanfaatkan modal sosial (social capital) semua kalangan masyarakat setempat, yakni dukungan semua kalangan, kepala dusun, tokoh agama dan adat serta generasi muda melalui sistem simpok yang nantinya dapat menarik perhatian pemerintah setempat untuk ikut membantu pengembangan wisata pedesaan.

Begitu banyak bantuan karena di lihat kita maju dan tidak pernah meminta, maka dibantu terus karena memang konsep pemerintah seperti itu. Silahkan bikin sendiri dulu, swadaya dulu. Karena pemerintah tidak akan memberikan bukti bantuan dari nol, dari mulai merintis. Pemerintah kan melihat ini siapa yang mau. Dilihat dari situ kemudian bantuan mengalir (IL02, KP).

Upaya-upaya yang dilakukan pengelola desa wisata untuk menstimulasi kesadaran semua unsur kalangan masyarakat tentang pentingnya support dari mereka dalam proses pengembangan pariwisata halal yang berkelanjutan di Desa Setanggor.

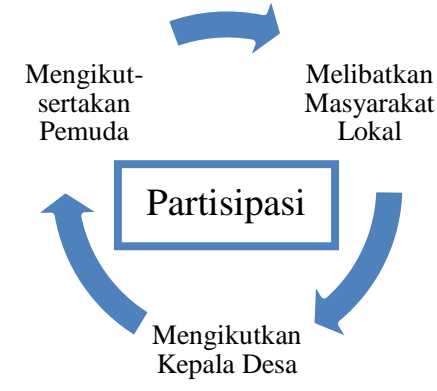

\section{Gambar 4.1 Pendekatan Partisipatif}

Oleh karena itu, pengembangan pariwisata halal Desa Setanggor dapat terwujud bila semua elemen yang terkait seperti pemerintah desa, masyarakat lokal (kepala dusun, tokoh agama dan adat) dan pemuda lokal dapat disinergikan secara maksimal. Karena merekalah yang memiliki sumber daya lokal, wawasan tentang potensi desa dan memahami kebutuhan-kebutuhan lainnya, sehingga semua kalangan masyarakat setempat perlu diberdayakan dalam proses pengembangan pariwisata halal di desa. Ini bermaksud agar melibatkan masyarakat setempat sebagai pelaku aktif dalam kegiatan pariwisata dan pengembangannya, karena tanpa dukungan mereka maka pengembangan desa wisata tidak bisa berjalan sesuai harapan.

Namun dalam pengembangan pariwisata Desa Setanggor, terdapat sebuah tantangan yang dihadapi, seperti rendahnya partisipasi pemuda pada tahap perencanaan dan pengambilan keputusan untuk mengembangkan pariwisata, serta pemuda lebih memilih mencari penghasilan diluar daerahnya karena kondisi ekonomi di desa belum menunjang, sehingga pemuda lokal kurang berpartisipasi dalam membangun pariwisata dilingkungannya (IP06, AKP). Ini menunjukan bahwa kesiapan sumber daya manusia (khususnya pemuda) dalam pengembangan pariwisata halal, masih belum memadai. Maka 


\section{NATIONALLY ACCREDITED JOURNAL - DECREE NO.21/E/KPT/2018}

dari itu, hal ini penting untuk diperhatikan oleh pengelola desa wisata halal Setanggor bila berharap konsep pariwisata halal dapat diterapkan secara maksimal dan berkelanjutan.

\subsection{Menawarkan Potensi Kelokalan}

Proses memetakkan potensi Desa Setanggor dilakukan dengan cara musyawarah seluruh komponen desa dari berbagai kalangan, baik itu perangkat desa, tokoh agama, tokoh masyarakat, kepala dusun, kelompok tani, kelompok pemuda maupun kelompok lainnya. Adapun potensi wisata yang dimiliki oleh Desa Setanggor, terdapat beberapa kelompok potensi yang dapat dipetakkan. Diantaranya adalah:

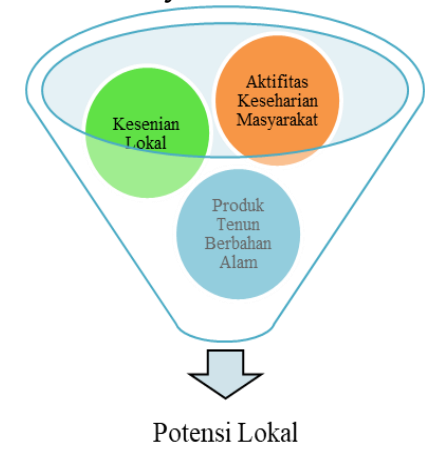

Gambar 4.2 Potensi Lokal

Dalam membentuk destinasi wisata, pengelola wisata berusaha menggali hal apa yang dapat disuguhkan kepada wisatawan. Mereka berupaya menyajikan aktifitas seharihari masyarakat lokal yang bekerja di area persawahan, perkebunan, dan menyuguhkan seni-budaya yang dimilikinya, serta menawarkan konsep pariwisata halal sebagai atraksi wisata. Ungkapan seorang informan bahwa

Pejuang awal-awal membuka beberapa destinasi seperti salah satunya gong tua, gamelan, ngaji tengah sawah, agrowisata, wisata pertanian, wisata tenun, wisata perkebunan (IL01, Kdus/Pok).

Aktifitas-aktifitas masyarakat setempat bisa menjadi daya tarik tersendiri dalam menciptakan pengalaman unik bagi wisatawan yang berkunjung di Desa Setanggor. Hal ini dilakukan supaya keberlanjutan desa wisata dapat diwujudkan, karena mereka sadari bahwa masyarakat sendiri yang ikut berpartisipasi secara langsung dan utuh untuk melayani wisatawan. Hal ini dilakukan untuk memperlihatkan bahwa desa mereka memiliki destinasi wisata yang dapat dikunjungi.

Artinya seluruh potensi lokal masyarakat bisa dijadikan sebagai mata pencaharian untuk menambah pemasukan (income) bagi masyarakat dan melestarikan seni budaya yang telah dimiliki Desa Setanggor. Oleh karena itu, bila dilihat dari sisi finansial, dengan adanya aktifitas pariwisata di desa masyarakat memperoleh pemasukan dari atraksi wisata yang dimilikinya.

\subsection{Menghadirkan Pengaruh Positif Pariwisata}

Aktifitas pariwisata yang ada di Desa Setanggor memberikan dampak positif pada peningkatan ekonomi masyarakat lokal. Kehadiran pariwisata di desa sangat diterima baik oleh masyarakat karena potensi-potensi yang mereka miliki dapat dinikmati oleh masyarakat lebih luas, tidak hanya memenuhi seremonial di kampung semata melainkan dapat ditampilkan pada agenda-agenda kedinasan dan penerimaan kunjungan dari pemerintah. Sehingga perlahan masyarakat mulai terbuka dengan pariwisata dengan segala aktifitasnya. Kehadiran pariwisata di Desa Setanggor memberikan pengaruh positif bagi banyak kelompok masyarakat Desa Setanggor. 


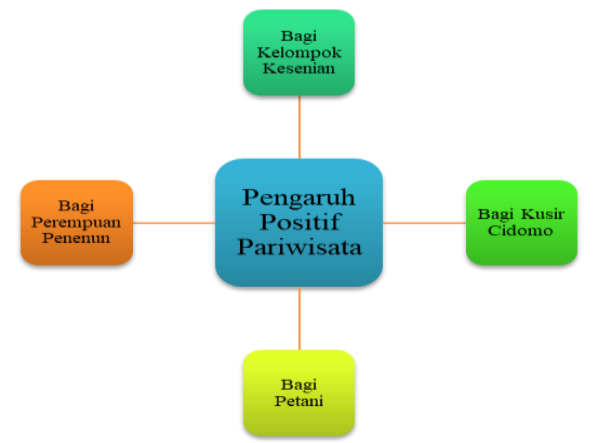

Gambar 4.3 Pengaruh Positif Pariwisata

Dalam konteks Setanggor, kehadiran industri pariwisata dapat memberikan manfaat secara ekonomi dan terjaganya ketahanan sosial-budaya masyarakat lokal serta mengurangi dampak negatif terhadap lingkungan. Oleh karena itu, antusiasme masyarakat yang tinggi dalam melihat sektor pariwisata bisa menjadi modal yang sangat berharga dalam membenahi dan membangun destinasi wisata yang memiliki peluang ekonomis bagi masyarakat lokal.

\subsection{Menguatkan Promosi Pariwisata}

Para pengelola desa wisata Setanggor beranggapan bahwa jantung kemajuan destinasi wisata ada pada kemampuan pengelola dalam memasarkan desa wisata kepada masyarakat lebih luas. Seperti ungkapan sesorang informan,

Ya itulah ya memang di promosi yang harus kuat, karena kalau tidak mampu di promosi susah juga (IL03, BP).

Pengelola wisata percaya bahwa dengan kemampuan mempromosikan potensi pariwisata desa mampu menarik minat berkunjung wisatawan untuk menikmati pengalaman berwisata di Desa Setanggor. Beragam cara yang dilakukan oleh pelaku wisata untuk mempromosikan desa wisata halal Setanggor yakni sebagai berikut;

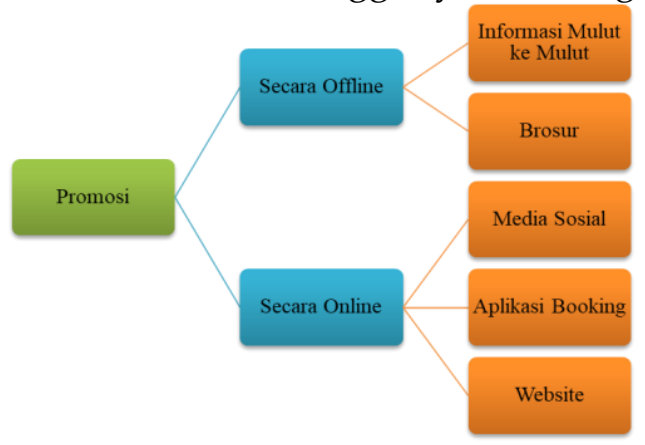

Gambar 4.4 Promosi

Strategi promosi seperti yang ditampilkan diatas sebagai upaya untuk mendorong bertambahnya kedatangan wisatawan domestik dan mancanegara ke Desa Setanggor. Hal ini dirasa penting oleh pengelola wisata, karena sebagus apapun daya tarik wisata yang dimiliki desa bila tidak dikuatkan dengan promosi maka informasi mengenai desa wisata Setanggor, lebih-lebih dengan merek (branding) pariwisata halal tidak akan tersampaikan ke masyarakat lebih luas.

\subsection{Membangun Kerjasama}

Pengembangan desa wisata halal di Desa Setanggor, tidak cukup dengan mengandalkan potensi masyarakat setempat, melainkan butuh kemampuan untuk membangun relasi dengan pihak luar untuk bersama-sama membangun pariwisata di desa. Pengelola wisata melakukan kerjasama dengan pihak-pihak, yang dalam hal ini dikenal 


\section{NATIONALLY ACCREDITED JOURNAL - DECREE NO.21/E/KPT/2018}

dengan konsep pentahelix (pemerintah, swasta, media, akademisi, dan komunitas). Menjalin mitra dengan pihak perguruan tinggi (akademik), pemerintah setempat dan komunitaskomunitas lainnya sebagai upaya untuk meningkatkan kapasitas SDM dalam mengembangkan pariwisata halal Desa Setanggor.

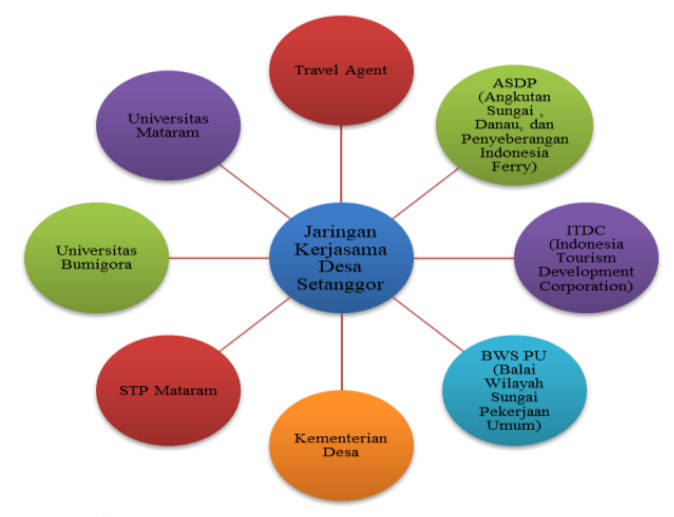

Gambar 4.5 Kerjasama Desa Setanggor

Merujuk dari gambar diatas, bahwa kemampuan untuk membangun relasi dengan pihak luar sangat dibutuhkan untuk bersama-sama mengembangkan wisata pedesaan. Keterlibatan stakeholder dalam bentuk kerjasama dengan pengelola pariwisata mampu menciptakan sistem yang lebih efektif dan efisien. Salah satu relasi yang kuat untuk membantu pengembangan pariwisata di Desa Setanggor ialah keterlibatan pemerintah khususnya pemerintah desa untuk mengadakan pelatihan keterampilan dan pengetahuan individu / kelompok terkait usaha di bidang pariwisata.

\section{KESIMPULAN DAN SARAN}

\subsection{Kesimpulan}

Dalam pengembangan pariwisata halal yang sesuai dengan kearifan lokal Muslim, pengelola wisata mengajak masyarakat, pemangku adat, tokoh agama, dan pemuda lokal untuk turut membangun dan menjaga kearifan lokal, dengan memanfaatkan modal sosial (social capital) semua kalangan masyarakat setempat dalam upaya melestarikan nilai-nilai kebudayaan di Desa Setanggor tidak punah, dengan berbasiskan masyarakat lokal. Lebih lanjut, pola yang diterapkan oleh pengelola wisata dikenal dengan "sistem simpok" secara swadaya dalam membangun desa wisata halal Setanggor, yakni sebuah strategi untuk menumbuhkan rasa tanggung jawab dan rasa kepemilikan pengelola wisata dalam proses pembangunan pariwisata halal di Desa Setanggor.

Kesediaan, semangat dan kemauan masyarakat lokal untuk berkorban dan berkontribusi terhadap pengembangan desa wisata dapat mempercepat arah pembangunan desa. Keterlibatan semua kalangan masyarakat merupakan modal utama untuk mempermudah program pembangunan Desa Setanggor, khususnya pada sektor pariwisata. Keberlanjutan pariwisata pedesaan sebagai inovasi baru (new innovation) mustahil dapat dijalankan tanpa partisipasi langsung dari masyarakat di destinasi wisata. Karena tanpa dukungan masyarakat secara moral dan materil, pengembangan desa wisata tidak dapat terjadi sesuai dengan harapan masyarakat Desa Setanggor. 


\subsection{Saran}

Hasil penelitian ini menunjukkan bahwa pengelola desa wisata Setanggor mengangkat konsep pariwisata halal sebagai merek (branding) pariwisatanya, konsep ini dilihat sangat relevan dengan keinginan masyarakat Desa Setanggor yang tetap menjaga kearifan lokal yang diyakininya. Hal ini dilakukan oleh pengelola wisata untuk menarik atensi dan minat berkunjung wisatawan mancanegara, lebih-lebih wisatawan Muslim. Namun peneliti berasumsi bahwa mem-branding nama Setanggor sebagai Desa Wisata Halal tidak cukup, melainkan pengelola wisata masih memerlukan inovasi lebih dalam upaya memperkuat branding Setanggor, seperti membuat slogan dan tagline untuk mendukung nama tersebut, yang dapat mencakup keseluruhan desa wisata meliputi: nilai, filosofi, budaya serta agama yang dianut oleh masyarakat setempat, agar semakin menarik dan mempermudah wisatawan dalam membedakan desa wisata yang berkonsep wisata halal dengan desa wisata yang lain.

\section{DAFTAR PUSTAKA}

Akyol M, \& Kilinc, O. (2014). Internet and Halal Tourism Marketing. International Periodical For The Languages. Literature and History of Turkish or Turkic, 9 (8): 171-186

Andriani, D. et al. (2015). Laporan Akhir Kajian Pengembangan Wisata Syariah. Jakarta: Deputi Bidang Pengembangan Kelembangaan Pariwisata.

Atmoko, T. P. H. (2014). Strategi pengembangan potensi desa wisata Brajan kabupaten Sleman. Media Wisata, 12(2).

BappedaNTB. (2018). NTB yang kami bayangkan, Mataram: Bappeda

Bastaman, A. (2018). Lombok Islamic Tourism Attractiveness: Non-Muslim Prespectives. Int. J Sup. Chain. Mgt, Vol. 7, No. 2, 206-210.

Battour, M., \& Ismail, M. N. (2016). Halal tourism: Concepts, practices, challenges and future. Tourism Management Perspectives, 19, 150-154.

Battour, M., Battor, M., \& Ismail, S. (2012). The mediating role of tourist satisfaction: a study of Muslim tourists in Malaysia. Journal of Travel and Tourism Marketing, Vol. 29 No. 3, 279-297.

Battour, M., Ismail, M., \& Battor, M. (2011). The impact of destination attributes on Muslim tourist's choice. International Journal of Tourism Research, Vol. 13 No. 6, 527-540.

Hermawan, H. (2016). Dampak pengembangan Desa Wisata Nglanggeran terhadap ekonomi masyarakat lokal. Jurnal Pariwisata, 3(2), 105-117.

Jaelani, A. (2017). Halal Tourism Industry in Indonesia: Potential and Prospects. International Review of Management and Marketing, Vol 7, Issue 3.

Jafari, J., \& Scott, N. (2014). Muslim world and its tourisms. Annals of Tourism Research, 44, 119.

Jannati, S. A., Ramadhan, D., \& Pertiwi, C. N. D. (2020). Modal Sosial Dalam Revitalisasi Kearifan Lokal (Studi Kasus Desa Wisata Kandri Kecamatan Gunung Pati Kota Semarang). Jurnal Analisa Sosiologi, 9.

Kemenparekraf. (2019). Siaran Pers: Lombok Terpilih Sebagai Destinasi Wisata Halal Terbaik di Indonesia, diunduh 1 Januari, 2021, dari https://www.kemenparekraf.go.id/index.php/post/siaran-pers-Lombokterpilih-sebagai-destinasi-wisata-halal-terbaik-di-indonesia.

Miles, M. B, \& Huberman, A. M. (2009), Analisis Data Kualitatif. Terjemahan: Tjetjep Rohendi Rohidi, Jakarta: UI Press.

Nassar, A. M., Mostafa, M. M., \& Reisinger, Y. (2015). Factors influencing travel to Islamic destinations: an empirical analysis of Kuwaiti nationals. International Journal of Culture, 114 Tourism and Hospitality Research, Vol. 9 No. 1, 36-53. 


\section{NATIONALLY ACCREDITED JOURNAL - DECREE NO. 21/E/KPT/2018}

Nisthar, S., \& Nufile, A. A. M. (2016). Impacts of Multidiscplinary Teaching of Islam on Tourism: A Study of Islamic Religious Perspective. International Journal of Advanced Research and Review (IJARR), 1(7); 73-82.

ntbprov.go.id (2019). Tetapkan 99 Desa, Pemprov Awali dengan 25 Desa Wisata diunduh 2 Januari, 2021, dari https://www.ntbprov.go.id/post/tetapkan-99-desa-pemprovawali-dengan-25-desa-wisata

Pearce, D. (1995). Tourism a Community Approach. 2nd: Harlow Longman.

Peraturan Daerah Provinsi Nusa Tenggara Barat Nomor 2 Tahun 2016 Tentang Pariwisata Halal.

Pew Research. (2015). Muslims, diunduh 2 Januari, 2020, dari https://www.pewforum.org/2015/04/02/Muslims/

Pratama, A. A. (2020). Pariwisata Halal Sebagai Konteks Keberlanjutan Industri Pariwisata Dalam Prespektif Generasi Muda Di Pulau Lombok. Tesis. Lombok: Program Studi Magister Manajemen Fakultas Ekonomi dan Bisnis Universitas Mataram

Priasukmana, S., \& Mulyadin, R. M. (2001). Pembangunan desa wisata: Pelaksanaan undangundang otonomi daerah. Info Sosial Ekonomi, 2(1), 37-44.

Samori, Z., Salleh, N. Z. M., \& Khalid, M. M. (2016). Current Trends in Halal Tourism: Case on selected Asian Countries. Tourism Management Perspectives, 19, 131-136.

Satriana, E. D., \& Faridah, H. D. (2018). Wisata Halal: Perkembangan, Peluang, dan Tantangan. Journal of Halal Product and Research (JHPR), Vol. 01 No.02.

Sriprasert, P., Chainin, O., \& Abd Rahman, H. (2014). Understanding behaviour and needs of Halal tourism in Andaman Gulf of Thailand: a case of Asian Muslim. Journal of Advanced Management Science, Vol. 2 No. 3, 216-219.

Sukmayeti, E., \& Utami, V. Y. (2018). Governansi Publik Model Co-Production oleh Aktor Socio-Preneur (Kasus Desa Setanggor Dan Kawis Krisant). Jurnal Ilmu Pemerintahan: Kajian Ilmu Pemerintahan dan Politik Daerah, Volume 3 - Nomor 2, 120-135.

Suwena, I. K. (2010). Pengetahuan Dasar Ilmu Pariwisata. Denpasar: Udayana Press.

Utami, V. Y. (2020). Dinamika Modal Sosial dalam Pemberdayaan Masyarakat pada Desa Wisata Halal Setanggor: Kepercayaan, Jaringan Sosial dan Norma. Reformasi, Volume 10 Nomor 1, 34-44.

Zamani-Farahani, H., \& Musa, G. (2012). The relationship between Islamic religiosity and residents' perceptions of socio-cultural impacts of tourism in Iran: Case studies of Sare' in and Masooleh. Tourism Management, 33 802-814. 